\title{
Implication of land use change to biogeophysical and biogeochemical processes in Jambi, Indonesia: Analysed using CLM5
}

\author{
Ummu Ma'rufah ${ }^{1}$, Tania June, ${ }^{1, *}$, Akhmad Faqih ${ }^{1}$, Ashehad Ashween Ali ${ }^{2}$, Christian Stiegler ${ }^{2}$, and \\ Alexander Knohl ${ }^{2}$ \\ ${ }^{1}$ Department of Geophysics and Meteorology, Faculty of Mathematics and Natural Sciences, IPB University, Campus IPB \\ Dramaga, Indonesia \\ ${ }^{2}$ Bioclimatology, Faculty of Forest Science, University of Göttingen, Göttingen, Germany
}

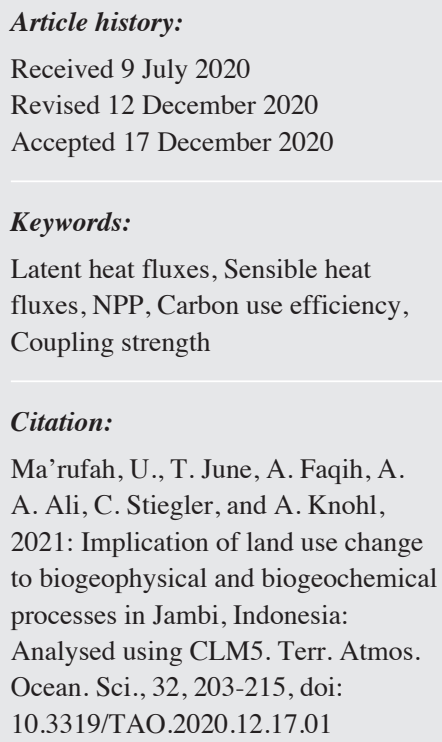

\begin{abstract}
Deforestation plays an essential role in land cover changes in tropical area. It resulted in changing surface biophysical characteristics such as albedo and surface roughness altering the climate, heat fluxes as well as $\mathrm{CO}_{2}$ fluxes. Thus, this study aims to analyse the biogeophysical and biogeochemical processes in forest, shrub, grass, and soybean. Also, the study analyses the coupling strength in the terrestrial segment. This analysis is conducted using the Community Land Model Version 5 (CLM5). The results showed that land-use changes alter surface heat fluxes. Forest changing into shrub, grass, and soybean decreased latent heat fluxes and increased sensible heat fluxes. Land-use changes also alter carbon uptake, although it did not necessarily reduce the net primary production (NPP) and efficiency. Forest changing into soybean will increase NPP, while its changes to grass and shrub will decrease NPP. Among all land covers, soybean had higher carbon use efficiency (CUE) due to the availability of water and soil nutrient supply. In comparison, the forest had lower CUE due to its high respiration to maintain its biomass. Coupling strength between soil moisture and latent heat fluxes in all land covers was positive, but the R-squared was relatively low. This result indicated that there was another factor impacting surface energy balance partition such as vegetation cover.
\end{abstract}

\section{INTRODUCTION}

Land use and land cover changes at a global scale have increased significantly over the last 300 years (Goldewijk and Ramankutty 2004). In tropical areas, land-use change usually relates to deforestation or forest degradation, such as in Indonesia (Boucher et al. 2011). From 1990 to 2012, Indonesia lost about 20.7 Mha of forest area, and the highest deforestation occurred in Sumatra and Kalimantan (Wijaya et al. 2015). Sumatra contributes to 8.6 Mha or about $41.5 \%$ of total national deforestation (Wijaya et al. 2015). It was higher than the deforestation in Kalimantan. One of the areas with extensive forest transformation on Sumatra Island is Jambi Province (Drescher et al. 2016). From 1990 to 2013, the declines in primary and secondary forest areas in Jambi Province were approximately about $38.2 \%$ (from

\footnotetext{
* Corresponding author

E-mail:taniajune@apps.ipb.ac.id
}

1.34 to $0.83 \mathrm{Mha}$ ) and $30.9 \%$ (from 0.92 to $0.64 \mathrm{Mha}$ ), respectively (Melati 2017).

Deforestation in Jambi was caused by the various driving factor such as forest fire, transmigration project, and land allocation to specific land-use such as plantation and dryland agriculture (Stolle et al. 2003). According to Melati (2017), degradation in the lowland forest in Jambi was most affected by easier accessibility and related to that reason palm oil and rubber plantation were most likely to be the driving factor of deforestation. In 2011, the dominant area in Jambi Province was dryland agriculture mixed with bush (37.1\%), followed by secondary forest $(18.9 \%)$ (Melati 2019). From 2009 to 2011, the loss of secondary forest was the highest among other forest covers lost it occurred due to the conversion into bare land and dryland agriculture mixed with bush (Melati 2019).

Deforestation resulted in changes in surface biophysical characteristics such as albedo and surface roughness 
influencing the climate (Burakowski et al. 2018). Land-use change will impact on the environment in many ways, some being changes in surface energy balance, water surface budget, and carbon cycle (Ibrom et al. 2007; Boisier et al. 2012; Ma et al. 2014). The impact of changing vegetation on climate varies depending on geographical location (Longobardi et al. 2016). Most studies showed that high latitude deforestation results in cooling, low latitude caused warming, and mid-latitude had mixed responses (Longobardi et al. 2016). Deforestation lead to warming in Jambi province. From 2000 to 2015, the land-use change caused morning and evening temperatures to increase for about $1{ }^{\circ} \mathrm{C}$ (Sabajo et al. 2017). Forest transformed into monoculture also causes the land to dry. According to Meijide et al. (2018), the transformation of forests to palm oil (rubber) resulted in the land becoming drier, about $11.9 \%$ (12.8\%). However, the surface temperature of mature palm oil, around 19 to 28 years old, was almost the same with primary and secondary forests (Artikanur and June 2019).

The impact of the land surface on the atmosphere can be categorized into two parts, i.e., soil moisture to surface fluxes and surface fluxes to atmosphere state and precipitation (Dirmeyer 2011). The terrestrial segment has been characterized by the correlation between soil moisture and evaporation (Chen and Dirmeyer 2017). A positive relationship showed that soil moisture controls the variation of evapotranspiration (Dirmeyer 2011). This positive correlation is necessary but not sufficient for a condition for the land surface to affect the atmosphere (Dirmeyer 2011; Williams and Torn 2015).

Forest conversion into tree crops including rubber and oil plantation occurred particularly between 1990 and 2000 (Melati 2017). Then, the oil palm plantation also took over rubber plantation due to its highly profitable source of income (Feintrenie et al. 2010; Melati 2017). However, in 2009 secondary forest mostly converted into bare land and dryland agriculture mixed with bush especially in Harapan Landscape (Melati 2019). Therefore, in this study we will try to analyse biogeophysical and biogeochemical processes of forest and the change of these processes if the forest is transformed into the shrub, grass, or dryland agriculture (soybean) using Community Land Model version 5 (CLM5). We will also conduct an analysis of coupling strength between land cover to the atmosphere near the surface through the interaction between soil moisture and surface fluxes.

\section{METHODOLOGY}

\subsection{Data}

The data used in this study were divided into two types, i.e., model simulation and model validation. CRUNCEP (Viovy 2018) was used for atmospheric data forcing in the model simulation. The dataset consisted of air temperature, solar radiation, specific humidity, air pressure, wind speed, and total precipitation rate with spatial resolution $0.5^{\circ}$ (latitude) $\times 0.5^{\circ}$ (longitude) and time resolution 6-hour. The data period for this simulation was from 2001 to 2016. Besides, aerosol data (available at https://svn-ccsm-inputdata.cgd.ucar.edu/trunk/inputdata/atm/cam/chem/trop mozart aero/aero/) and concentration of $\mathrm{CO}_{2}$ data (available at https://svn-ccsm-inputdata.cgd.ucar.edu/trunk/inputdata/ atm/datm7/CO2/) were also used. In the model simulation, surface data were also needed. Thus, the study used data from Hassler et al. (2015) consisting of the presentation of clay and sand from depth 0 to $200 \mathrm{~cm}$. Data for model validation were from the meteorological station of CRC990 EFForTS, including solar radiation, temperature, wind speed, pressure, and humidity. Some of the station data are inside the plot and some are outside. The available data was in 10 minutes, and the data period was from 2013 to 2016.

\subsection{Model Simulation}

The model used in this study was the Community Land Model version 5 (CLM5) (Lawrence et al. 2019). This model is the land component of the Community Earth System Model (CESM) version 2.1.0. Model spinups were run 600 years to reach the equilibrium condition. The biochemistry (BGC) model was activated, meaning that vegetation state, e.g., height, steam, and leaf amounts were calculated prognostically. The aerosol model for the atmospheric data was set to transient 1850 to the year 2000 conditions, and the type of input $\mathrm{CO}_{2}$ was set to diagnostic. In this study, point simulations were used running at the HF1 plot of the EFForTS project (Drescher et al. 2016) in Harapan Forest (Fig. 1). The first simulation used PFT for forest, broadleaf evergreen tree-tropical (BET-Tropical). Therefore, the study simulated land use change and PFT changes into three types of vegetation, including shrub, grass, and tropical soybean. For each PFT, default phenology value was used for parameters because the data were not available.

\subsection{Model Evaluation}

The output model was evaluated using calculation data from the meteorological station. Output data used in this analysis were sensible heat fluxes, latent heat fluxes, net radiation, NPP, GPP, and respiration. However, the model evaluation was only done for net radiation and latent heat because there was no available observation data for other variables. Net radiation $\left(R_{n}\right)$ was the difference between net shortwave $\left(R_{n s}\right)$ and net longwave $\left(R_{n l}\right)$ radiation:

$R_{n}=R_{n s}+R_{n l}$

Net shortwave radiation and net longwave radiation were calculated as below: 
$R_{n s}=(1-\alpha) R_{s}$

and

$R_{n l}=\sigma T^{4}\left(0.34-0.14 \sqrt{e_{a}}\right) f$

Where $\alpha$ is the albedo, $R_{s}$ is solar radiation $\left(\mathrm{MJ} \mathrm{m}^{-2} \mathrm{hr}^{-1}\right), \sigma$ is Stefan-Boltzmann constant $\left(2.043 \times 10^{-10} \mathrm{MJ} \mathrm{K}^{-4} \mathrm{~m}^{-2} \mathrm{hr}^{-1}\right)$, $T$ hourly air temperature $(\mathrm{K}), e_{a}$ is actual vapour pressure $(\mathrm{kPa})$, and $f$ is cloud cover factor. The hourly average of latent heat fluxes was calculated using FAO Penman-Monteith (Allen et al. 1998):

$E T_{0}=\frac{0.408 \Delta R_{n}+\gamma[37 /(T+273)] U_{2}\left(e_{s}-e_{a}\right)}{\Delta+\gamma\left(1+0.34 U_{2}\right)}$

Where $E T_{0}$ is potential evaporation $\left(\mathrm{mm} \mathrm{hr}^{-1}\right), R_{n}$ is net radiation $\left(\mathrm{MJ} \mathrm{m}^{-2} \mathrm{hr}^{-1}\right), T$ is mean hourly air temperature $\left({ }^{\circ} \mathrm{C}\right), U_{2}$ is average hourly wind velocity at $2-\mathrm{m}$ above ground $\left(\mathrm{m} \mathrm{s}^{-1}\right)$, $e_{s}$ is saturation vapor pressure $(\mathrm{kPa}), e_{a}$ is average hourly actual vapor pressure $(\mathrm{kPa}), \Delta$ slope curve between vapor pressure and air temperature $\left(\mathrm{kPa}^{\circ} \mathrm{C}^{-1}\right)$, and $\gamma$ is psychrometric constant $\left(\mathrm{kPa}^{\circ} \mathrm{C}^{-1}\right)$. For the $E T_{c}, E T_{0}$ is multiplied by $\mathrm{kc}$ value of evergreen broadleaf forest (Liu et al. 2017) and then latent heat is calculated as below:

$L E=E T_{c} L$
Where $L E$ is latent heat $\left(\mathrm{W} \mathrm{m}^{-2}\right)$ and $L$ is energy for evaporation $\left(2.45 \times 10^{6} \mathrm{~J} \mathrm{~kg}^{-1}\right)$.

\subsection{Analysis of Land Surface Impact on Surface Energy Balance}

Land cover and surface interactions can be analyzed by dividing them into two segments (Chen and Dirmeyer 2017). Terrestrial segments analyze the interaction between soil moisture in the morning with surface flux in the morning. This analysis is done by coupling strength index, which is calculated by the following equation:

$C S_{L}=\operatorname{corr}(S M, L H) \sigma_{L H}$

Where $S M$ is the soil moisture in the morning at a depth of $10 \mathrm{~cm}, L H$ is latent heat in the morning, corr is the Pearson correlation coefficient, and $\sigma$ is the standard deviation. In the terrestrial segment, $S M$ can also be changed with LAI data.

\section{RESULTS AND DISCUSSION}

\subsection{Model Evaluation}

This study performs model evaluation specifically for the forest area because the observation data is only available for this land cover. The evaluated variables are net radiation and latent heat fluxes, since there is no eddy tower in the

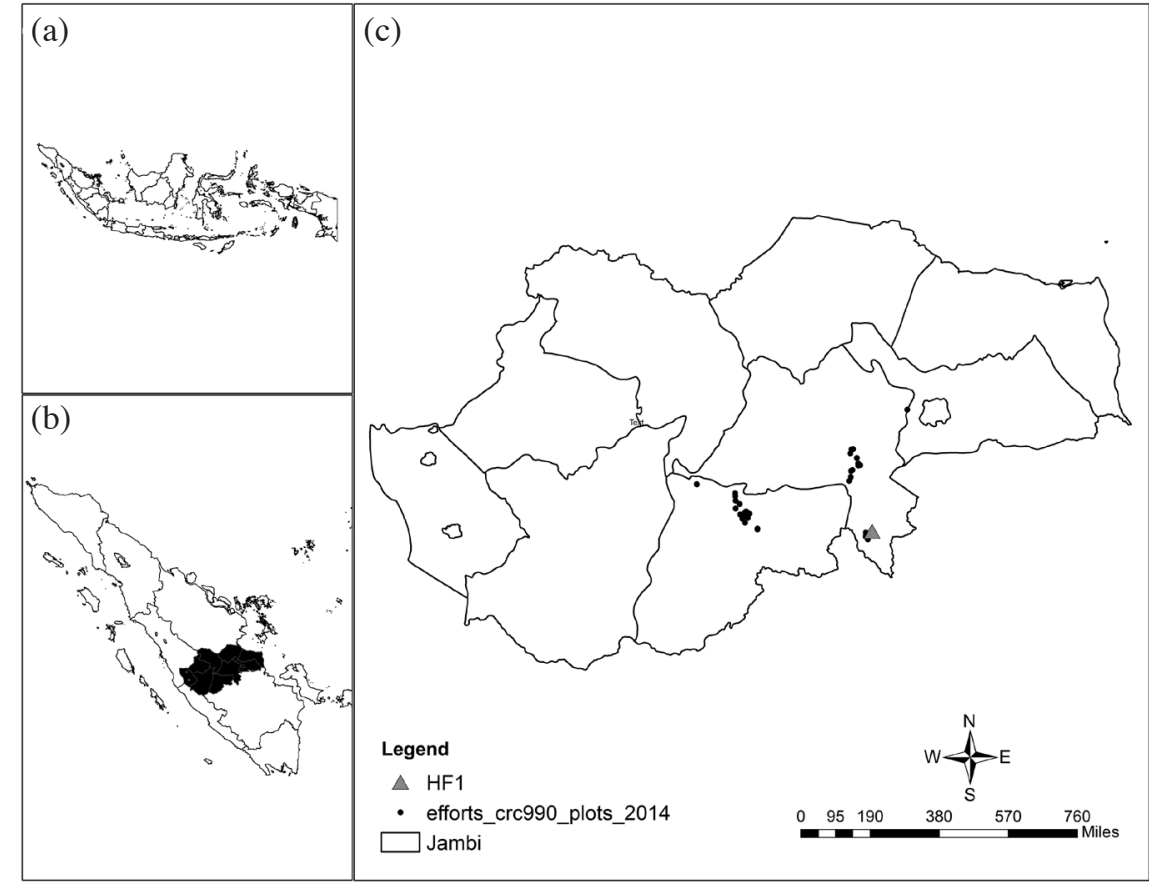

Fig. 1. Location map of the study area, Jambi Province in Sumatra Island of Indonesia (a) (b). The triangle is HF1 plot of the EFForTS project used for simulation (c). 
forest to assess variable of biogeochemical process. The performance of CLM5 in simulating net radiation and latent heat fluxes is showed in Taylor diagram (Fig. 2; Taylor 2001). The circle in $\mathrm{x}$-axis show perfect fit between model and observation. Therefore, label closed to the circle represent perfect model simulation. Net radiation is simulated well in CLM5 with correlation coefficient 0.89 and centered rootmeans-square (RMS) less than 1 . The standard deviation of net radiation is also close to one. It means that the model has the same standard deviation values as the observation. In contrast, latent heat fluxes have high standard deviation and the label is far from the circle. This poor performance could be influenced by differences in the spatial resolution of the climate. The model uses large scale climate while in this model evaluation we use calculations from local climate data. However, the coefficient correlation of latent heat fluxes is still high, about 0.84. Therefore, the CLM is acceptable for the analysis of biogeophysical processes in this study.

\subsection{Surface Energy Balance in Forest, Shrub, Grass, and Soybean}

The forest fire is one of the factors causing forest loss and degradation. After the fire, burned forests usually become shrub or grassland. Sometimes, the community also converts forests into dryland for agriculture, such as soybean. Therefore, analysis of surface energy balance of forest, shrub, grass, and soybean is vital in understanding how climate will change if the forest is converted to those land use covers. The monthly data of surface energy balance is analysed during 2001 to 2015. Partition of surface energy balance from forest, shrub, grass, and soybean is showed in Fig. 3.

Partition of surface energy balance from forest, shrub, grass, and soybean show higher utilization of energy for latent heat fluxes. This result indicates adequate availability of water in the region, and energy is not a limiting factor. Forest, shrub, and grass are evergreen plants, so the partition of surface fluxes does not fluctuate, while in soybean, the surface fluxes changes dramatically. This pattern follows the planting time of soybean. The net radiation in soybean is slightly lower than other land use (Figs. 3 and 4). Surface albedo of soybean is high, so most of solar energy will return to atmosphere. It also has high ground temperature (Fig. 5). This high ground temperature in soybean cause loss more energy in the form of longwave radiation, so net radiation become lower than other land-use cover. Ground temperature of shrub and grass are almost similar (Fig. 5). Forest has lower ground temperature than shrub and grass but the magnitude is not much different. Therefore, net radiation of forest, shrub, and grass is about the same in magnitude.

In seasonal variation, net radiation in forest, shrub, and grass is slightly decline from June to July and it could be occur due to decreasing incoming solar radiation (Fig. 4). The study area is located in southern hemisphere with latitude $2.19 \mathrm{~S}$. Therefore, from June to July, incoming solar radiation slightly decrease because sun position is in northern hemisphere. Latent heat fluxes in forest, shrub, and grass is high in March to April and October to November. This variation may affected by rainfall pattern in which Jambi Province has two peak rainy season i.e., April and November (Drescher et al. 2016; Sari et al. 2018). Sensible heat fluxes in forest, shrub, and grass is relatively constant over the year. In soybean area, net radiation decline from April to September. During this period, the area of soybean become bare land and it will increase surface albedo. Surface with high albedo will absorb less radiation, so net radiation will decrease. High latent heat fluxes and low sensible heat fluxes in soybean occur during planting time. Simulation of soybean uses crop irrigated type, so during planting time, water is always available, leading to higher evapotranspiration. In contrast, during the non-planting time, the soybean

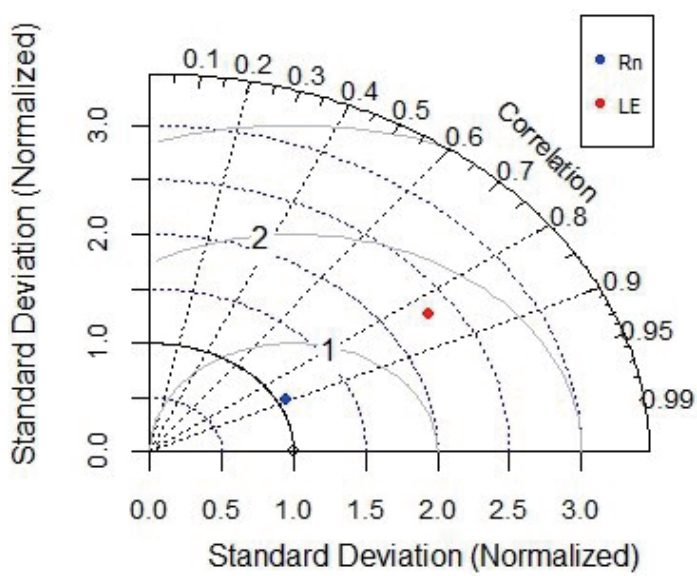

Fig. 2. Taylor diagram summarizing standard deviation (y-axis), correlation coefficient (arc-axis), and centered root mean square (gray circle) between CLM and observation data of net radiation (blue) and latent heat flux (red). 

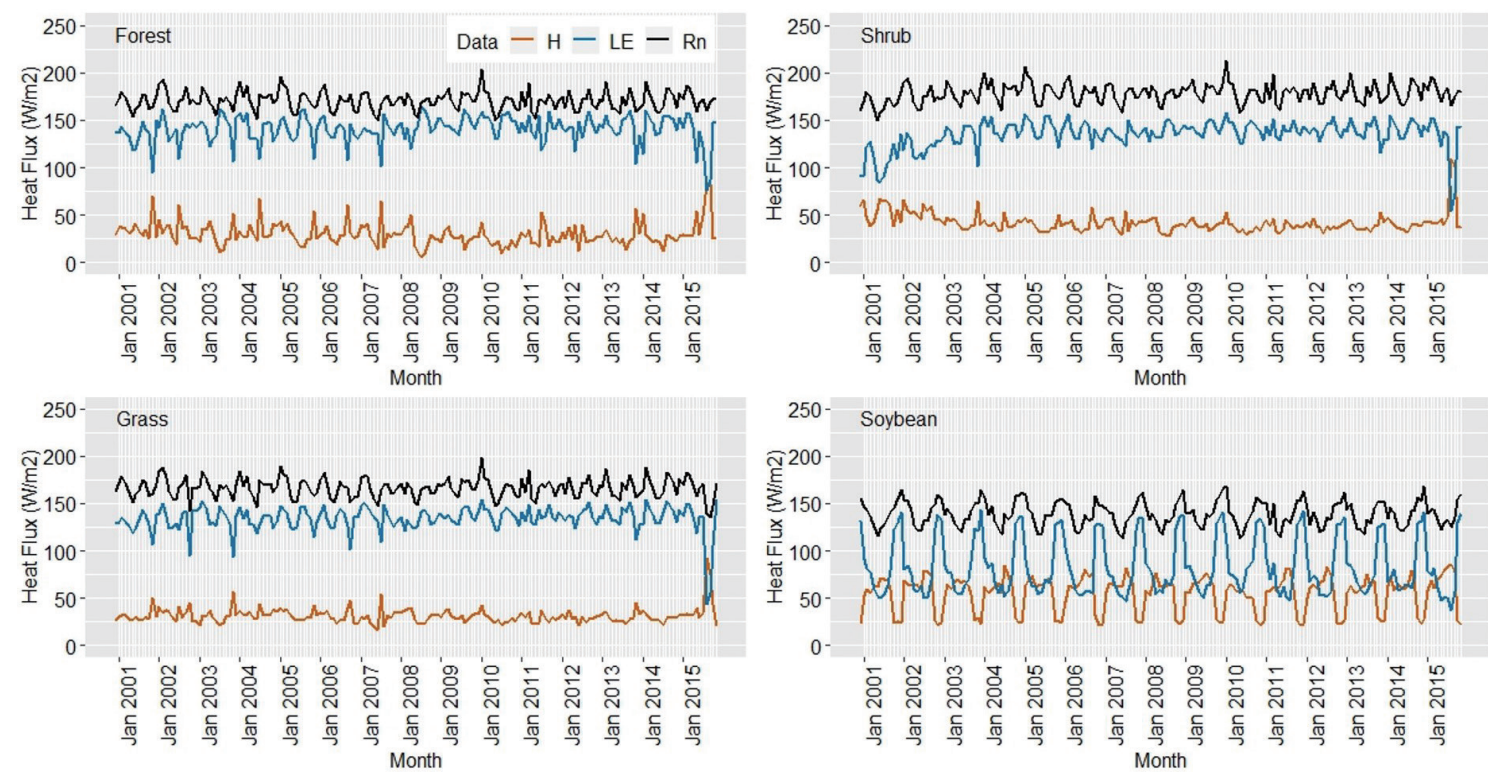

Fig. 3. Monthly time series data of sensible heat fluxes (H), latent heat fluxes (LE), and net radiation (Rn) in forest, shrub, grass, and soybean from 2001 to 2015.
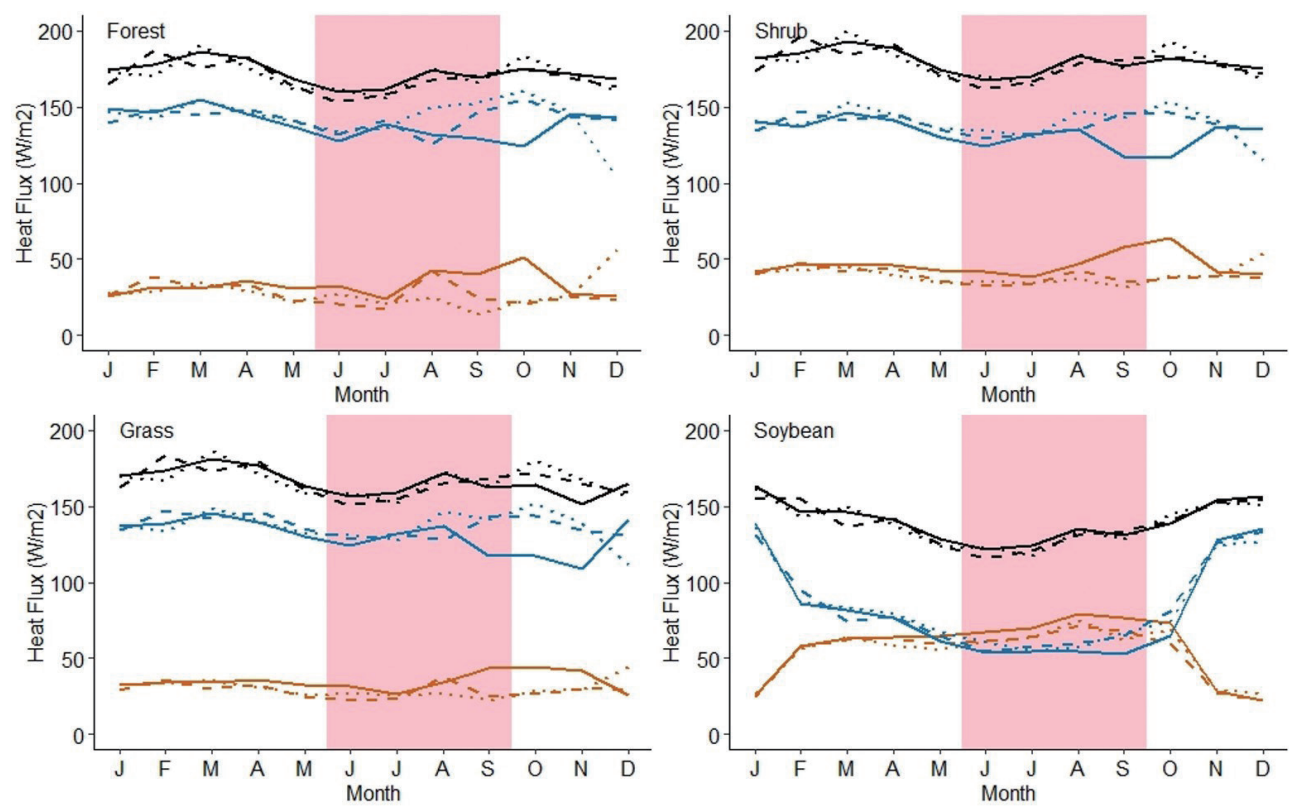

$$
\begin{aligned}
& \text { - H_El_Nino - LE_El_Nino - Rn_El_Nino } \\
& \text { - H_La_Nina - - LE_La_Nina - Rn_La_Nina } \\
& \cdots \text { H_Normal } \cdots \text { LE Normal } \cdots \text { Rn Normal }
\end{aligned}
$$

Fig. 4. Average data of sensible heat fluxes (H), latent heat fluxes (LE), and net radiation (Rn) in El Niño, La Niña, and Normal years. Pink shade area denote dry season period and white shade area denote rainy season. 


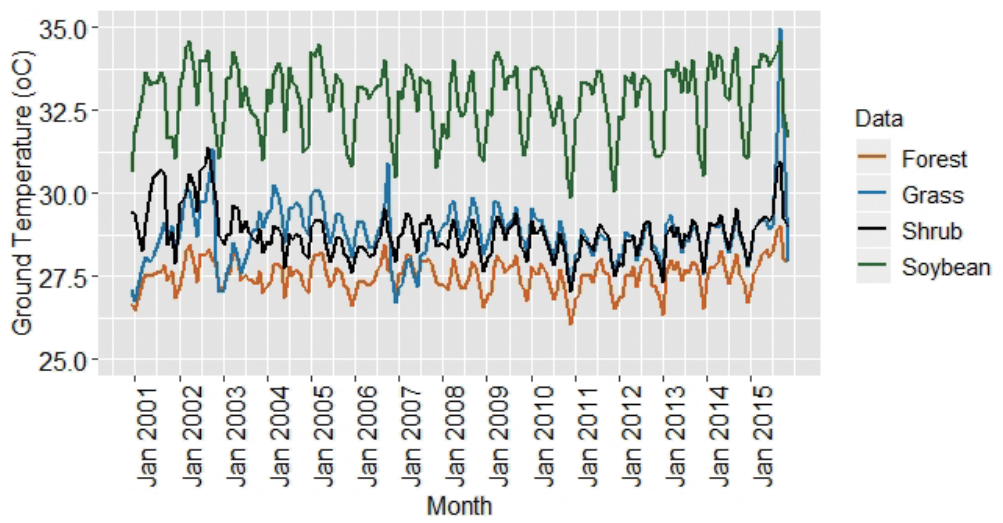

Fig. 5. Monthly time series of ground temperature in forest, shrub, grass, and soybean from 2001 to 2015.

area will become bare land that is not irrigated. Therefore, evapotranspiration will decrease, and most of the available energy will be used for heating.

La Niña event does not has high effect on changing surface energy balance. During La Niña years, the amount of net radiation, sensible heat fluxes, and latent heat fluxes are not change considerably (Fig. 4). In contrast, El Niño has high impact on changing the partition of surface energy balance particularly from September to November (Fig. 4). It is occur because El Niño cause significant deficit rainfall in most of Indonesian region in boreal autumn (Iskandar et al. 2019). This reduction of rainfall decrease water availability leads to declining evapotranspiration and increasing sensible heat fluxes. From 2001 to 2015, El Niño occur four times i.e., 2002, 2006, 2009, and 2015. Weak and moderate El Niño in 2002, 2006, and 2009 has not obvious impact on surface energy balance while in 2015, strong El Niño has significant effect on decreasing latent heat fluxes and increasing latent heat fluxes (Fig. 3).

In 2015, strong El Niño had a high impact on water availability due to deficit rainfall. When land experience water stress, most available energy would not be used for heating. In this year, Jambi also experience land fire caused canopy scorch and smoke. Canopy damage is likely to reduce transpiration and it will impact on changing surface heat fluxes partition (Beringer et al. 2003). Sensible heat fluxes will dominant rather than latent heat fluxes. Smoke absorbed and scattered solar radiation lead to decrease in incoming solar radiation (Stiegler et al. 2019). Decreasing downward solar radiation along with drought and heat stress triggered partial stomata closure that reduced evapotranspiration and latent heat fluxes (Stiegler et al. 2019). Among all land use covers, the forest still had high latent heat during strong El Niño (Fig. 3). Tree, type of forest vegetation, has a long root zone. During the long dry season, the tree can take water from deep soil, so it may not experience water stress. In addition, forest is more stable in term of biophysical function during strong El Niño. It shows that forest is able to deal with drought stress as discussed in Lohbeck et al. (2020).

Forest changing into shrub, grass, or soybean has an impact on latent and sensible heat fluxes. Impact of El Niño to surface energy balance is high from September to November. Thus, analysis the effect of forest cover change to latent and sensible heat fluxes focus on the period of September to November. From 2001 to 2015, forest cover changed into those land uses that had decreased latent heat fluxes and increased sensible heat fluxes (Fig. 6a). When forests change into shrub, grass, and soybean, albedo will increase, resulting in a reduction in absorbed radiation. Besides, surface roughness would decrease, impacting on the reduction of turbulence fluxes. Turbulence is essential to transfer latent heat fluxes and sensible heat fluxes. According to Burakowski et al. (2018) and June et al. (2018), surface roughness is a dominant biophysical factor contributing to differences in heat fluxes between forest and palm oil plantation (Burakowski et al. 2018; June et al. 2018). In strong El Niño, decreasing latent heat fluxes and increasing latent heat fluxes due to forest cover change is higher than in the period of 2001 to 2015 (Fig. 6b). However, forest changing into soybean shows different behaviour. Decreasing latent heat fluxes in strong El Niño is lower than in the period of 2001 to 2015. During El Niño years, the magnitude of latent and sensible heat flux in soybean is similar with Normal and La Niña years, while forest experience decreasing latent heat fluxes and increasing sensible heat fluxes (Fig. 4). Therefore during September to November, the impact of forest change into soybean on decreasing latent heat fluxes is lower in El Niño 2015 than in the period of 2001 to 2015 .

Forest and shrub have more significant fluctuations in Bowen ratio $(\beta)$, but soybean conserve this fluctuation (Fig. 7). Soybean (cropland) has a smaller change in $\beta$ which is about 0.3 to 0.4 . It is mainly due to soil water dynamic. This cropland uses the irrigating system, so the water is not a limitation for evaporation. Bowen ratio of shrub is about 0.25 to 0.5 . A higher variation of $\beta$ in a shrub is mainly due 

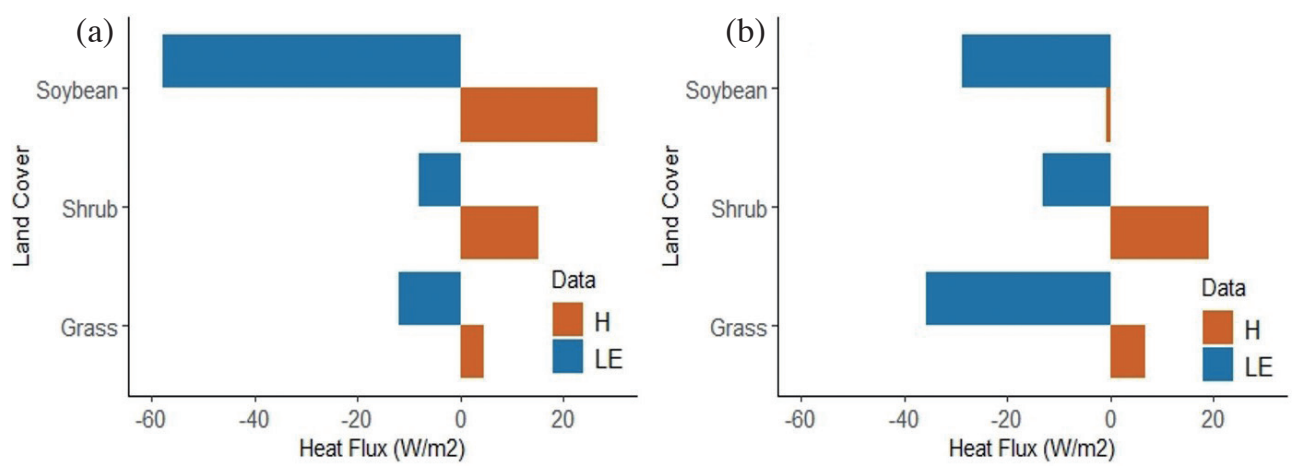

Fig. 6. Surface heat fluxes change from forest to shrub, grass, and soybean from 2001 to 2015 (a) and from 2015 (b). The value is average data from September to November.

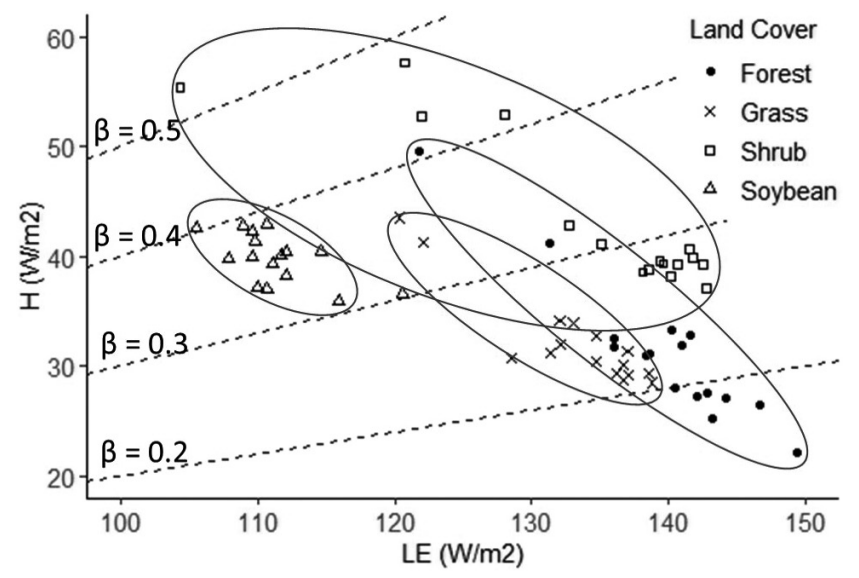

Fig. 7. Annual average sensible and latent heat fluxes in different land use types. Dash line show the value of Bowen ratio.

to more significant changes in LAI. In 2001 - 2003, shrub had low growth, and during this period, sensible heat fluxes was high. In the following year, LAI of shrub was high, leading to an increase in latent heat fluxes. Forest and grass have Bowen ratio value $0.1-0.4$ and $0.2-0.35$, respectively. The variation of LAI in forest and grass are small, and the fluctuation of $\beta$ may be due to soil water dynamic.

\subsection{Primary Production}

Net Primary Production (NPP) is a residual between gross primary production (GPP) and autotrophic respiration (Ra). Those values can be used to understand the biogeochemical process in the terrestrial ecosystem. In the monthly scale, NPP and GPP in forest, shrub, and grass are always constant (Fig. 8). In 2001 and 2002, NPP and GPP of the shrub were mostly low because the land cover changing process in this simulation started in 2001. Therefore, during that period, shrub had a low leaf area index (LAI) that led to low GPP and NPP. For soybean, GPP and NPP are very fluctuating because soybean is not an evergreen plant. High GPP and NPP occur during the planting period and low during the non-planting period. In seasonal variation, dry and rainy season do not impact on GPP and NPP. The magnitude of GPP in forest, shrub, and grass are slightly low in June to July (Fig. 9). It corresponds to decreasing net radiation during this period.

La Niña event does not effect on carbon absorption, while El Niño impact on decreasing GPP and NPP (Fig. 9). In El Niño years, the decline in GPP and NPP occur between September and November. It corresponds to the decreasing of net radiation and latent heat fluxes that also occur between September and November. Forest, shrub, and grass have different respond to El Niño event. Decreasing GPP and NPP in forest only occur in El Niño 2015 (Fig. 8). In shrub, GPP and NPP decline in El Niño 2006 and 2015. Grass is more sensitive to El Niño event than forest and shrub. It experience decreasing GPP and NPP three times, i.e., El Niño 2002, 2006, and 2015. Grass has shorter root depth than forest and shrub (Schenk and Jackson 2002). Thus, grass more sensitive to drought because it cannot access to deep water source. In strong El Niño, severe drought also trigger grass mortality (Breshears et al. 2016).

In 2015, primary production was low in all land 

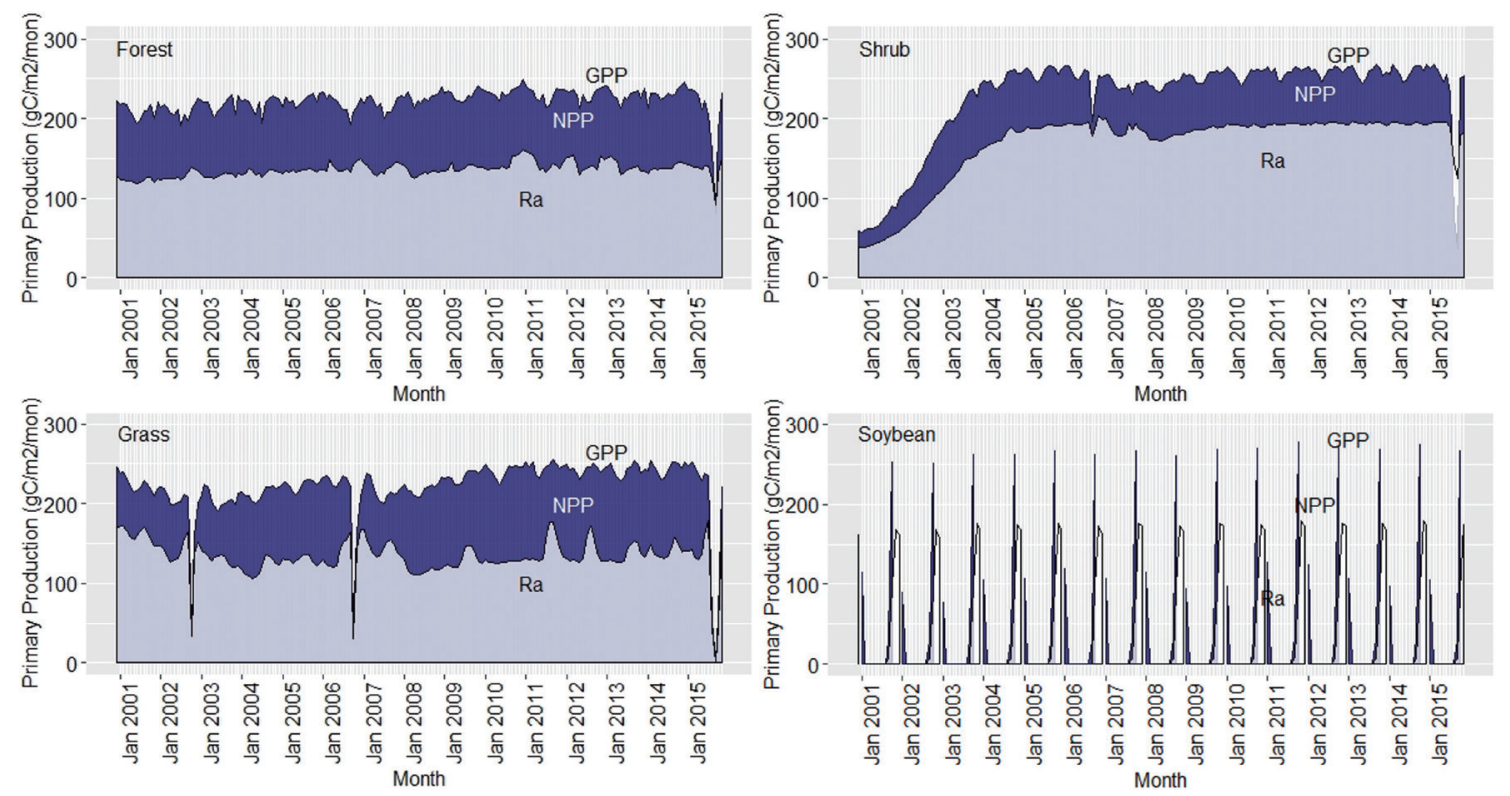

Fig. 8. Monthly time series data of GPP, NPP, and autotropic respiration (Ra) in forest, shrub, grass, and soybean from 2001 to 2015.
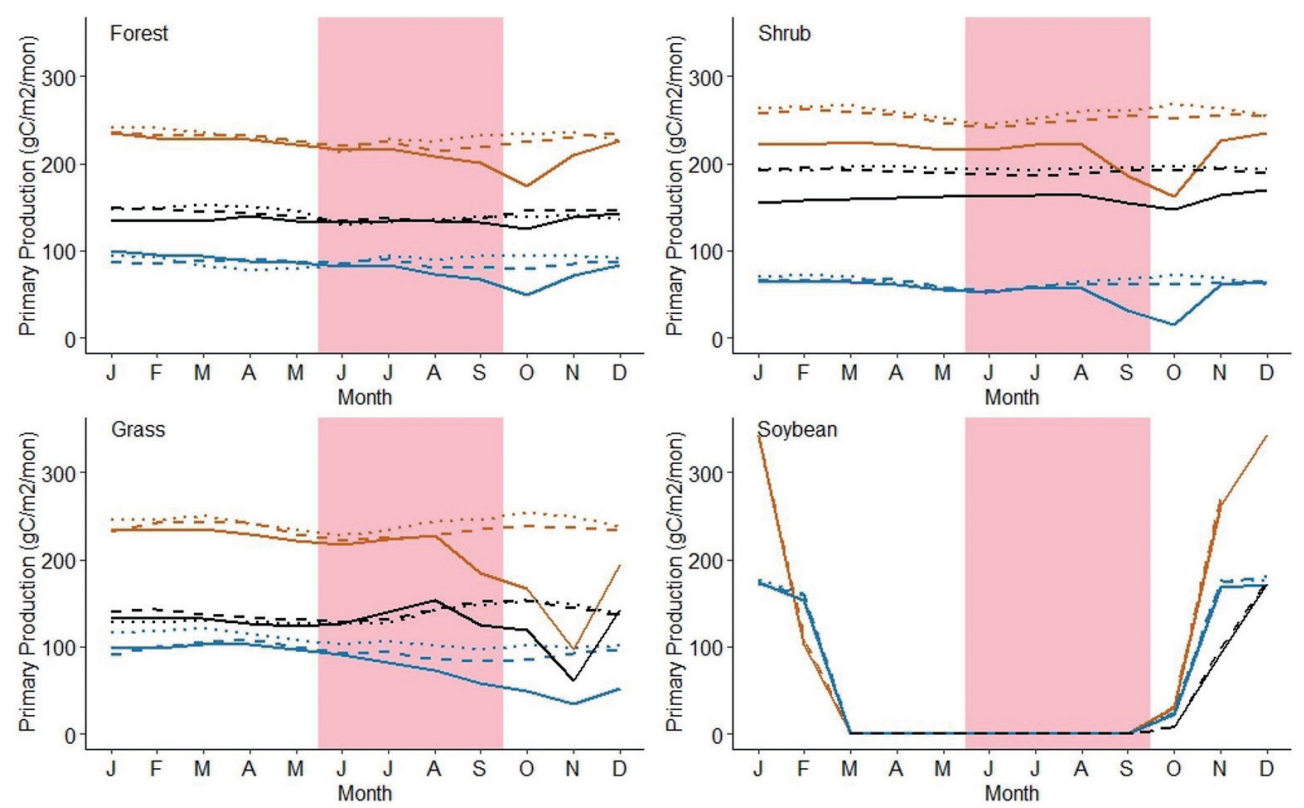

- GPP_EI_Nino

- NPP_EI_Nino

- Ra_El_Nino

... GPP_Normal

- NPP_La_Nina

- Ra_La_Nina

... Ra_Normal

Fig. 9. Average data of GPP, NPP, and autotropic respiration (Ra) in El Niño, La Niña, and Normal years. Pink shade area denote dry season period and white shade area denote rainy season. 
cover. During this period, El Niño had a high impact on GPP and NPP. Jambi was covered by smog due to forest fire. This smog reduces incoming solar radiation and decrease the photosynthesis process. Therefore, vegetation has low carbon absorption. Also, the deficit in rainfall over a couple of months cause water stress. Thus, the plant will increase its resistance to decreasing transpiration. As water is precious for capturing carbon, increasing water stress leads to decreasing carbon absorption. Most of the absorbed carbons are also used for maintenance respiration, leading to reducing in NPP. This result is also in line with the study of Gushchina et al. (2019) in which robust El Niño 2015 also affected the weakening NPP in tropical rainforest in Central Sulawesi due to an increase in air temperature. Similarly, in a nearby oil palm plantation carbon uptake was reduced by $86 \%$ during the smoke period in the ENSO 2015 (Stiegler et al. 2019).

Forest changing into shrub, grass, or soybean has a different impact on primary production (Fig. 10). Impact of El Niño to carbon absorption is high from September to November. Thus, analysis the effect of forest cover change to GPP and NPP focus on the period of September to November. Generally from 2001 to 2015 , changing forest to the other land-use cover cause decrease in GPP and NPP (Fig. 10a). LAI of forest is larger than grass and soybean, so capturing carbon though photosynthesis is also larger than those land-use cover. Broadleaf evergreen trees have a large biome, so most of the carbon absorption will be allocated for metabolic respiration. Consequently, forest will have low NPP than the other land-use. However, during September to November it occur the opposite condition. Forest always has high NPP unless in 2015, while in some years shrub and grass have low NPP due to water stress. During strong El Niño, changing forest into shrub and grass decrease primary production (Fig. 10b). Reducing carbon absorption is done to overcome water stress. However, the carbon uptake of the forest is still higher because forests can face drought stress better. In contrast, soybean has higher NPP than forest. In October and November, soybean is entering planting time. NPP in soybean always high during planting time although it is in El Niño years (Fig. 9).

Carbon use efficiency (CUE) is defined as ratio between net primary productivity (NPP) and gross primary productivity (GPP). CUE varied by land uses covering types with the higher value found in soybean $(0.64)$, followed by grass (0.40), forest (0.38), and shrub (0.27) (Fig. 11). CUE of soybean is significantly higher than that of the forest. In comparison with natural vegetation, CUE of irrigated soybean is higher due to the availability of water and also soil nutrient supply (Chen and Yu 2019). CUE of grass is higher than the forest, but the difference is not significant. Lower CUE in the forest is mainly caused by higher respiration for maintaining forest biomass compared to other land use types (Tang et al. 2019). For shrub, low CUE is also influ- enced by its high autotrophic respiration

\subsection{Coupling Strength in Terrestrial Segment}

Land-use change can lead to major change in local surface energy and water budgets and therefore to atmospheric stability. In the water cycle, soil moisture and evapotranspiration affect each other. Further, surface evapotranspiration will moisten the boundary layer and influence precipitation (Chen and Dirmeyer 2017). In this study, we just focus on terrestrial segment of the land-atmosphere coupling strength. The terrestrial segment has been characterized by the correlation in time between variations in soil moisture and latent heat fluxes. In forest, shrub, grass, and soybean, the coupling strength between soil moisture and latent heat fluxes is positive (Fig. 12a), indicating that the wet (dry) soil will increase (decrease) latent heat fluxes. However, the R-squared value for whole time series between soil moisture and latent heat fluxes is relatively low (Fig. 12b). There are several factors that cause a weak land segment of land-atmosphere coupling. Some vegetation has long root and it will take water for transpiration from deeper soil layer. Therefore, soil layer must be considered in the assessments of land-atmosphere coupling strength. Soil moisture and evapotranspiration also have nonlinear relationship in which vegetation tend to growth if soil water is available. In addition, transpiration strongly related to photosynthesis process and it is influenced by other factors such as biogeochemical processes. According to Williams et al. (2016), leaf area index (LAI) is more sensitive to evaporative fraction than soil moisture. It also implies that vegetation cover also plays a vital role in surface energy balance partitioning than soil moisture.

\section{CONCLUSION}

Land use changes can alter surface heat fluxes. Forest changing to shrub, grass, and soybean decreases latent heat fluxes and increases heat fluxes sensibility. It is more intense during El Niño years, especially in 2015. High LAI and surface roughness mainly cause high latent heat and low sensible heat in the forest. Shrub and forest have larger fluctuations in Bowen ratio $(\beta)$, but soybean conserved this fluctuation. Land use changes can also alter carbon absorption. Forest changing into shrub, grass, and soybean had a different impact on primary production. Forest turning into soybean increased NPP, while forest changing to grass and shrub would decreased NPP. In the strong El Niño event, all primary production significantly decreased when forest change to those land cover. Land use change may increase the efficiency of carbon storage. Among all land covers, soybean had higher CUE due to the availability of water and soil nutrient supply. In comparison, the forest had lower CUE due to its high respiration for maintaining forest 

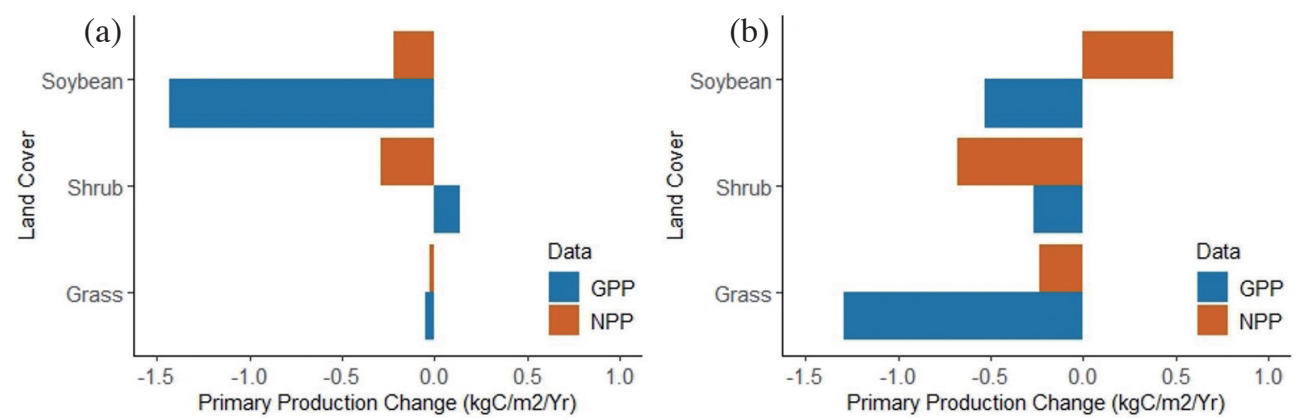

Fig. 10. Primary production change from forest to shrub, grass, and soybean from 2001 to 2015 (a) and 2015 (b). The value is average data from September to November.

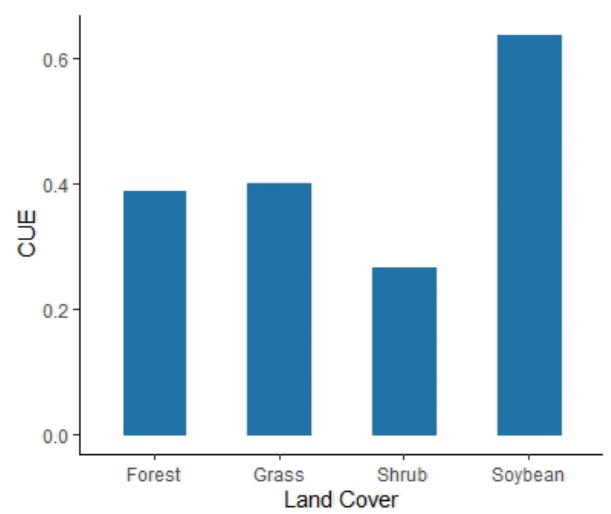

Fig. 11. Carbon Use Efficiency (CUE) in forest, shrub, grass, and soybean.
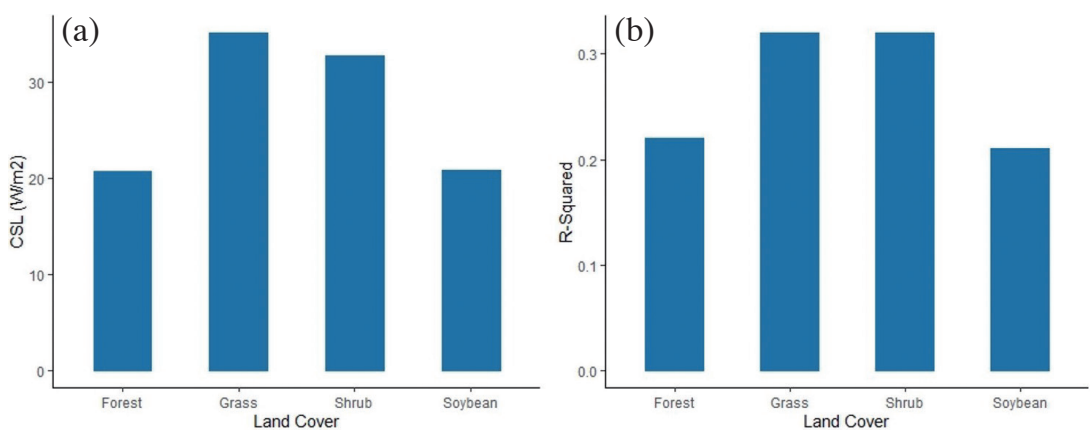

Fig. 12. Land-atmosphere coupling strength in land segment (CSL) (a) and R-Squared between soil moisture and latent heat fluxes (b). 
biomass. Land cover can control climate conditions in the region. Coupling strength between soil moisture and latent heat fluxes in all land cover is positive, but the R-squared is relatively low. This result means that soil moisture is not a significant factor impacting on latent heat fluxes variation. LAI may be more sensitive to evapotranspiration rather than soil moisture. Therefore, vegetation cover plays a vital role in surface energy balance partitioning rather than the land surface state.

Acknowledgements This study was supported by Collaborative Research Centre 990: Ecological and Socioeconomic Functions of Tropical Lowland Rainforest Transformation Systems (EFForTS) funded by the German Research Foundation. This output has also been funded in part by Master to Doctoral Programme for Outstanding Undergraduate Students (PMDSU), Directorate General of Higher Education, Ministry of National Education, Indonesia.

\section{REFERENCES}

Allen, R. G., L. S. Pereira, D. Raes, and M. Smith, 1998: Crop Evapotranspiration: Guidelines for Computing Crop Water Requirements, FAO Irrigation and Drainage Paper 56, Food and Agriculture Organization of the United Nations, Rome, 74 pp.

Artikanur, S. D. and T. June, 2019: Surface temperature and heat fluxes: Comparison between natural forest and oil palm plantation in Jambi Province using Surface Energy Balance Algorithm for Land (SEBAL). Agromet, 33, 62-70, doi: 10.29244/j.agromet.33.2.62-70. [Link]

Beringer, J., L. B. Hutley, N. J. Tapper, A. Coutts, A. Kerley, and A. P. O'Grady, 2003: Fire impacts on surface heat, moisture and carbon fluxes from a tropical savanna in northern Australia. International Journal of Wildland Fire, 12, 333-340, doi: 10.1071/WF03023. [Link]

Boisier, J. P., N. de Noblet-Ducoudré, A. J. Pitman, F. T. Cruz, C. Delire, B. J. J. M. van den Hurk, M. K. van der Molen, C. Müller, and A. Voldoire, 2012: Attributing the impacts of land-cover changes in temperate regions on surface temperature and heat fluxes to specific causes: Results from the first LUCID set of simulations. J. Geophys. Res., 117, doi: 10.1029/2011JD017106. [Link]

Boucher, D., P. Elias, K. Lininger, C. May-Tobin, S. Roquemore, and E. Saxon, 2011: The Root of the Problem: What's Driving Tropical Deforestation Today? Cambridge, UCS Publications, 113 pp.

Breshears, D. D., A. K. Knapp, D. J. Law, M. D. Smith, D. Twidwell, and C. L. Wonkka, 2016: Rangeland Responses to Predicted Increases in Drought Extremity. Rangelands, 38, 191-196, doi: 10.1016/j. rala.2016.06.009. [Link]

Burakowski, E., A. Tawfik, A. Ouimette, L. Lepine, K.
Novick, S. Ollinger, C. Zarzycki, and G. Bonan, 2018: The role of surface roughness, albedo, and Bowen ratio on ecosystem energy balance in the Eastern United States. Agric. For. Meteorol., 249, 367-376, doi: 10.1016/j.agrformet.2017.11.030. [Link]

Chen, L. and P. A. Dirmeyer, 2017: Impacts of land-use/ land-cover change on afternoon precipitation over North America. J. Clim., 30, 2121-2140, doi: 10.1175/ JCLI-D-16-0589.1. [Link]

Chen, Z. and G. Yu, 2019: Spatial variations and controls of carbon use efficiency in China's terrestrial ecosystems. Sci.Rep., 9, doi: 10.1038/s41598-019-56115-5. [Link]

Dirmeyer, P. A., 2011: The terrestrial segment of soil moisture-climate coupling. Geophys. Res. Lett., 38, doi: 10.1029/2011GL048268. [Link]

Drescher, J., K. Rembold, K. Allen, P. Beckschäfer, D. Buchori, Y. Clough, H. Faust, A. M. Fauzi, D. Gunawan, D. Hertel, B. Irawan, I. N. S. Jaya, B. Klarner, C. Kleinn, A. Knohl, M. M. Kotowska, V. Krashevska, V. Krishna, C. Leuschner, W. Lorenz, A. Meijide, D. Melati, M. Nomura, C. Pérez-Cruzado, M. Qaim, I. Z. Siregar, S. Steinebach, A. Tjoa, T. Tscharntke, B. Wick, K. Wiegand, H. Kreft, and S. Scheu, 2016: Ecological and socio-economic functions across tropical land use systems after rainforest conversion. Phil. Trans. Biol. Sci., 371, 20150275, doi: 10.1098/ rstb.2015.0275. [Link]

Feintrenie, L., W. K. Chong, and P. Levang, 2010: Why do Farmers Prefer Oil Palm? Lessons Learnt from Bungo District, Indonesia. Small-Scale For., 9, 379-396, doi: 10.1007/s11842-010-9122-2. [Link]

Goldewijk, K. K. and N. Ramankutty, 2004: Land use changes during the past 300 years. Land Use, Land Cover and Soil Sciences, Vol. I, Encyclopedia of Life Support Systems (EOLSS), 147-168.

Gushchina, D., F. Heimsch, A. Osipov, T. June, A. Rauf, H. Kreilein, O. Panferov, A. Olchev, and A. Knohl, 2019: Effects of the 2015-2016 El Niño event on energy and $\mathrm{CO}_{2}$ fluxes of a tropical rainforest in central Sulawesi, Indonesia. Geography, Environment, Sustainability, 12, 183-196, doi: 10.24057/2071-9388-2018-88. [Link]

Hassler, E., M. D. Corre, A. Tjoa, M. Damris, S. R. Utami, and E. Veldkamp, 2015: Soil fertility controls soil-atmosphere carbon dioxide and methane fluxes in a tropical landscape converted from lowland forest to rubber and oil palm plantations. Biogeosciences, 12, 58315852, doi: 10.5194/bg-12-5831-2015. [Link]

Ibrom, A., A. Oltchev, T. June, T. Ross, H. Kreilein, U. Falk, J. Merklein, A. Twele, G. Rakkibu, S. Grote, A. Rauf, and G. Gravenhorst, 2007: Effects of land-use change on matter and energy exchange between ecosystems in the rain forest margin and the atmosphere. In: Tscharntke, T., C. Leuschner, M. Zeller, E. Guhardja, and A. Bidin (Eds.), Stability of Tropical Rainforest Margins: 
Linking Ecological, Economic and Social Constraints of Land Use and Conservation, Environmental Science and Engineering (Environmental Science), Springer, Berlin, Heidelberg, 461-490, doi: 10.1007/978-3-54030290-2_22. [Link]

Iskandar, I., D. O. Lestrai, and M. Nur, 2019: Impact of El Niño and El Niño Modoki Events on Indonesian Rainfall. Makara Journal of Science, 23, 217-222, doi: 10.7454/mss.v23i4.11517. [Link]

June, T., A. Meijide, C. Stiegler, A. P. Kusuma, and A. Knohl, 2018: The influence of surface roughness and turbulence on heat fluxes from an oil palm plantation in Jambi, Indonesia. IOP Conference Series: Earth and Environmental Science, 149, 012048, doi: 10.1088/1755-1315/149/1/012048. [Link]

Lawrence, D. M., R. A. Fisher, C. D. Koven, K. W. Oleson, S. C. Swenson, G. Bonan, N. Collier, B. Ghimire, L. Kampenhout, D. Kennedy, E. Kluzek, P. J. Lawrence, F. Li, H. Li, D. Lombardozzi, W. J. Riley, W. J. Sacks, M. Shi, M. Vertenstein, W. R. Wieder, C. Xu, A. A. Ali, A. M. Badger, G. Bisht, M. Broeke, M. A. Brunke, S. P. Burns, J. Buzan, M. Clark, A. Craig, K. Dahlin, B. Drewniak, J. B. Fisher, M. Flanner, A. M. Fox, P. Gentine, F. Hoffman, G. Keppel-Aleks, R. Knox, S. Kumar, J. Lenaerts, L. R. Leung, W. H. Lipscomb, Y. Lu, A. Pandey, J. D. Pelletier, J. Perket, J. T. Randerson, D. M. Ricciuto, B. M. Sanderson, A. Slater, Z. M. Subin, J. Tang, R. Q. Thomas, M. Val Martin, and X. Zeng, 2019: The Community Land Model version 5: Description of new features, benchmarking, and impact of forcing uncertainty. J. Adv. Model. Earth Syst., 11, 4245-4287, doi: 10.1029/2018MS001583. [Link]

Liu, C., G. Sun, S. G. McNulty, A. Noormets, and Y. Fang, 2017: Environmental controls on seasonal ecosystem evapotranspiration/potential evapotranspiration ratio as determined by the global eddy flux measurements. Hydrol. Earth Syst. Sci., 21, 311-322, doi: 10.5194/ hess-21-311-2017. [Link]

Lohbeck, M., P. Albers, L. E. Boels, F. Bongers, S. Morel, F. Sinclair, B. Takoutsing, T.-G. Vågen, L. A. Winowiecki, and E. Smith-Dumont, 2020: Drivers of farmermanaged natural regeneration in the Sahel. Lessons for restoration. Sci. Rep., 10, doi: 10.1038/s41598-02070746-z. [Link]

Longobardi, P., A. Montenegro, H. Beltrami, and M. Eby, 2016: Deforestation Induced Climate Change: Effects of Spatial Scale. PLoS One, 11, e0153357, doi: 10.1371/journal.pone.0153357. [Link]

Ma, E., X. Deng, Q. Zhang, and A. Liu, 2014: Spatial variation of surface energy fluxes due to land use changes across China. Energies, 7, 2194-2206, doi: 10.3390/ en7042194. [Link]

Meijide, A., C. S. Badu, F. Moyano, N. Tiralla, D. Gunawan, and A. Knohl, 2018: Impact of forest conversion to oil palm and rubber plantations on microclimate and the role of the 2015 ENSO event. Agric. For. Meteorol., 252, 208-219, doi: 10.1016/j.agrformet.2018.01.013. [Link]

Melati, D. N., 2017: The use of remote sensing data to monitor land use systems and forest variables of the tropical rainforest landscape under transformation in Jambi Province, Sumatra, Indonesia. Ph.D. Thesis, Faculty of Forest Sciences and Forest Ecology, Georg-AugustUniversity of Göttingen, $112 \mathrm{pp}$.

Melati, D. N., 2019: Carbon Emission Estimation Due to Land Cover Change in the Tropical Forest Landscape in Jambi Province. Jurnal Sains dan Teknologi Mitigasi Bencana, 14, 27-34, doi: 10.29122/jstmb. v14i1.3561. [Link]

Sabajo, C. R., G. le Maire, T. June, A. Meijide, O. Roupsard, and A. Knohl, 2017: Expansion of oil palm and other cash crops causes an increase of the land surface temperature in the Jambi province in Indonesia. Biogeosciences, 14, 4619-4635, doi: 10.5194/bg-14-4619-2017. [Link]

Sari, F. N., T. June, and A. Knohl, 2018: Dynamics of the Standardized Precipitation Evapotranspiration Index (SPEI) of an oil palm plantation area in Jambi Province, Indonesia. IOP Conference Series: Earth and Environmental Science, 187, 012065, doi: 10.1088/17551315/187/1/012065. [Link]

Schenk, H. J. and R. B. Jackson, 2002: Rooting depths, lateral root spreads and below-ground/above-ground allometries of plants in water-limited ecosystems. J. Ecol., 90, 480-494, doi: 10.1046/j.1365-2745.2002.00682.x. [Link]

Stiegler, C., A. Meijide, Y. Fan, A. Ashween Ali, T. June, and A. Knohl, 2019: El Niño-Southern Oscillation (ENSO) event reduces $\mathrm{CO}_{2}$ uptake of an Indonesian oil palm plantation. Biogeosciences, 16, 2873-2890, doi: 10.5194/bg-16-2873-2019. [Link]

Stolle, F., K. M. Chomitz, E. F. Lambin, and T. P. Tomich, 2003: Land use and vegetation fires in Jambi Province, Sumatra, Indonesia. For. Ecol. Manage., 179, 277292, doi: 10.1016/S0378-1127(02)00547-9. [Link]

Tang, X., N. Carvalhais, C. Moura, B. Ahrens, S. Koirala, S. Fan, F. Guan, W. Zhang, S. Gao, V. Magliulo, P. Buysse, S. Liu, G. Chen, W. Yang, Z. Yu, J. Liang, L. Shi, S. Pu, and M. Reichstein, 2019: Global variability of carbon use efficiency in terrestrial ecosystems. Biogeosciences, doi: 10.5194/bg-2019-37. (preprint) [Link]

Taylor, K. E., 2001: Summarizing multiple aspects of model performance in a single diagram. J. Geophys. Res., 106, 7183-7192, doi: 10.1029/2000JD900719. [Link]

Viovy, N., 2018: CRUNCEP Version 7 - Atmospheric Forcing Data for the Community Land Model. Research Data Archive at the National Center for Atmospheric 
Research, Computational and Information Systems Laboratory, doi: 10.5065/PZ8F-F017. [Link]

Wijaya, A., R. A. Sugardiman Budiharto, A. Tosiani, D. Murdiyarso, and L. V. Verchot, 2015: Assessment of Large Scale Land Cover Change Classifications and Drivers of Deforestation in Indonesia. Int. Arch.Photogramm. Remote Sens. Spatial Inf. Sci., XL-7/W3, 557562, doi: 10.5194/isprsarchives-XL-7-W3-557-2015. [Link]
Williams, I. N. and M. S. Torn, 2015: Vegetation controls on surface heat flux partitioning, and land-atmosphere coupling. Geophys. Res. Lett., 42, 9416-9424, doi: 10.1002/2015GL066305. [Link]

Williams, I. N., Y. Lu, L. M. Kueppers, W. J. Riley, S. C. Biraud, J. E. Bagley, and M. S. Torn, 2016: Landatmosphere coupling and climate prediction over the U.S. southern great plains. J. Geophys. Res., 121, 12125-12145, doi: 10.1002/2016JD025223. [Link] 